\title{
CHARACTERIZING MUSCLE ARTIFACT INTERFERENCE IN AEP RECORDING
}

\author{
Sandeep Maruthy, G. Nike Gnanateja, Resmitha Ramachandran, Priyanka Thuvassery \\ Electrophysiology Lab, Department of Audiology, All India Institute of Speech and Hearing, Mysore, India
}

Corresponding author: Sandeep Maruthy, Department of Audiology, All India Institute of Speech and Hearing, Mysore, India, e-mail: msandeepa@gmail.com

\begin{abstract}
Background: It is well known that muscle artifacts negatively affect auditory evoked potential (AEP) recordings. However, the precise relation between the set of muscles involved and the specific AEP affected is not clear. Most audiologists believe that increase in the tension of any muscle in the body would affect all AEPs to the same extent, while some believe that only head and neck muscles affect AEPs. Logically, this relation will depend on the frequency characteristics of the muscle artifact. However, to the best of our knowledge, there is no scientific documentation of the extent of interference created by various muscle responses on auditory brainstem responses (ABRs), middle latency responses (MLRs), and late latency responses (LLRs). The present study therefore sought to analyse the minimum artifact rejection threshold required for ABR, MLR, and LLR under various artifact-inducing conditions.
\end{abstract}

Material and methods: The present study involved 40 individuals of age 17 to 24 years. For each participant, the effects of muscle artifacts on three popular, clinically relevant AEPs (ABR, MLR, and LLR) were determined. First, recording was done in a rest condition where participants were seated in a reclining chair and asked to close their eyes and maintain a relaxed position. Then the participants were asked to carry out one of the following tasks: blink their eyes continuously; spread their lips; or stiffen their neck, hand, or leg muscles maximally. While tensing each of these set of muscles, the minimum artifact rejection threshold (MART) was noted.

Results: The results showed that each of the artifact-inducing conditions affected the three target AEPs differently. At rest, there was no significant difference in MART across the three AEPs, but artifact-inducing conditions produced different effects.

Conclusions: Not all artifacts affect every AEP equally. For good AEP recordings one needs to have a clear understanding of various muscle potentials and their relative effect on each AEP.

Key words: artifacts $\bullet$ auditory evoked potentials $\bullet$ signal-to-noise ratio

\section{CARACTERÍSTICAS DE LA INTERFERENCIAS PROVENIENTES DE LOS ARTEFACTOS MUSCULARES EN SEÑALES AUDITIVAS DE POTENCIALES EVOCADOS}

\section{Resumen}

Introducción: Se sabe que los artefactos musculares tienen un impacto negativo sobre las señales auditivas de los potenciales evocados (AEP). Sin embargo, se desconoce una relación precisa entre el conjunto de músculos afectados y la influencia en un potencial concreto. La mayoría de los audiólogos consideran que el aumento de la tensión de cualquier músculo influye en cierto modo en AEP, mientras que otros piensan que sólo los músculos de la cabeza y del cuello influyen en AEP. Desde un punto de vista lógico esta relación dependerá de la frecuencia de los artefactos musculares. No obstante, según el conocimiento de los autores hasta ahora no se ha documentado el ámbito de la interferencia entre diferentes respuestas de los músculos y potenciales auditivos del tronco cerebral (ABR), respuestas MLR y LLR. Por eso, el objetivo del presente trabajo es un análisis de un umbral mínimo del rechazo del artefacto imprescindible para ABR, MLR y LLR y en diferentes estados de evocación de artefactos.

Materiales y métodos: En el examen participaron 40 personas entre 17 y 24 años. Para cada participante se determinó la influencia de los artefactos musculares en tres potenciales conocidos clínicos aplicados durante el descanso, los participantes estaban en sillones plegables, se les pidió que cerraran los ojos y siguieran en posición de relajarse. Luego se les pidió de realizaran una de las siguientes tareas: parpadear los ojos de forma ininterrumpida, extender las comisuras, tensar lo más posible los músculos del cuello, las manos y las piernas. Durante la tensión de cada grupo de músculos se examinó el umbral mínimo del rechazo del artefacto (MART). 
Resultados: Los resultados muestran que cada estado que evoca los artefactos influye de manera diferente en tres potenciales auditivos finales. Durante el descanso no había diferencias considerables en el umbral MART en relación a estos tres potenciales, pero los estados que evocaban los artefactos tenían tres resultados diferentes.

Conclusiones: No todos los artefactos tenían la misma influencia en los potenciales auditivos evocados. Para conseguir buenas señales de los potenciales auditivos evocados es imprescindible conocer con precisión diferentes potenciales musculares y sus influencias correspondientes en cada potencial AEP.

Palabras clave: artefactos • potenciales auditivos evocados • relación entre la señal y el ruido

\section{ХАРАКТЕРИСТИКА ИНТЕРФЕРЕНЦИИ, ИСХОДЯЩЕЙ ИЗ МЫШЕЧНЫХ АРТЕФАКТОВ В СИГНАЛАХ СЛУХОВЫХ ВЫЗВАННЫХ ПОТЕНЦИАЛОВ}

\section{Изложение}

Введение: Известно, что мышечные артефакты оказывают отрицательное влияние на сигналы звуковых вызванных потенциалов (АЕР). Однако, неизвестным является точное соотношение между группой задействованных мышц и влиянием на конкретный потенциал. Большинство аудиологов считает, что рост напряжения каких-либо мышц до определенной степени оказывает влияние на АЕР, тогда как другие считают, что только мышцы головы и шеи влияют на АЕР. С логической точки зрения это соотношение будет зависеть от частотной характеристики мышечных артефактов. Однако, согласно знаниям авторов, до сих пор не был документирован объем интерференции между разными ответами мышц и слуховыми стволомозговыми ответами (ABR), средне латентными (MLR) и поздно латентными (LLR) ответами. Следственно, целью настоящей работы является анализ минимального порога отвержения артефакта, необходимого для ABR, MLR и LLR в разных состояниях возбуждения артефактов.

Материал и методы: В исследовании участвовало 40 человек в возрасте от 17 до 24 лет. Для каждого участника было определено влияние мышечных артефактов на три известные, клинически использованные слуховые потенциалы (ABR, MLR, LLR). Сначала измерение было произведено в условиях неподвижного состояния - участники сидели на раскладных креслах, их попросили закрыть глаза и остаться в расслабленном состоянии. Затем их попросили, чтобы они выполнили одно из следующих заданий: беспрерывно моргали глазами, растянули уголки рта, максимально напрягли мышцы шеи, руки или ноги. Во время напряжения каждой группы мышц, был исследован порог отвержения артефакта (MART).

Результаты: Результаты показывают, что каждое состояние, вызывающее артефакты, разным способом оказывало влияние на три целевые слуховые потенциалы. В неподвижном состоянии не было существенных разниц в пороге MART относительно этих трех потенциалов, но состояния, вызывающие артефакты, имели разные последствия.

Выводы: Не все артефакты оказывали одинаковое влияние на слуховые вызванные потенциалы. Чтобы получить хорошие сигналы слуховых вызванных потенциалов, необходимым является точное понимание разных мышечных потенциалов и их соответствующего влияния на каждый потенциал АЕР.

Ключевые слова: артефакты • слуховые вызванные потенциалы • отношение сигнала к шуму

\section{CHARAKTERYSTYKA INTERFERENCJI POCHODZĄCYCH Z ARTEFAKTÓW MIĘŚNIOWYCH W SYGNAŁACH SŁUCHOWYCH POTENCJAŁÓW WYWOŁANYCH}

\section{Streszczenie}

Wprowadzenie: Wiadome jest, że artefakty mięśniowe mają negatywny wpływ na sygnały słuchowych potencjałów wywołanych (AEP). Jednakże, nie jest znana dokładna relacja pomiędzy zespołem zaangażowanych mięśni i wpływem na konkretny potencjał. Większość audiologów uważa, że wzrost napięcia jakichkolwiek mięśni wpływa do pewnego stopnia na AEP, podczas gdy inni uważają, że tylko mięśnie głowy i szyi wpływają na AEP. Z logicznego punktu widzenia, relacja ta będzie zależała od charakterystyki częstotliwościowej artefaktów mięśniowych. Jednakże, wedle wiedzy autorów, nie udokumentowano dotąd zakresu interferencji pomiędzy różnymi odpowiedziami z mięśni a słuchowymi potencjałami z pnia mózgu (ABR), odpowiedziami średnioletencyjneymi (MLR) oraz późnolatencyjnymi (LLR). Dlatego też celem niniejszej pracy jest analiza minimalnego progu odrzucenia artefaktu niezbędnego dla ABR, MLR i LLR w różnych stanach wywołania artefaktów. 
Materiał i metody: W badaniu udział wzięło 40 osób w wieku pomiędzy 17 a 24 lat. Dla każdego uczestnika określono wpływ artefaktów mięśniowych na trzy znane, klinicznie stosowane potencjały słuchowe (ABR, MLR, LLR). Najpierw pomiar wykonywany był w warunkach spoczynku - uczestnicy siedzieli na rozkładanych fotelach, zostali poproszeni, żeby zamknąć oczy i pozostać w pozycji zrelaksowanej. Następnie poproszono ich aby wykonali jedno z następujących zadań: nieprzerwanie mrugali oczami, rozciągnęli kąciki ust, maksymalnie spięli mięśnie szyi, ręki lub nogi. Podczas napinania każdej partii mięśni, badano minimalny próg odrzucenia artefaktu (MART).

Wyniki: Wyniki pokazują, że każdy stan wywołujący artefakty wpływał w różny sposób na trzy docelowe potencjały słuchowe. W spoczynku nie było znaczących różnic w progu MART odnośnie tych trzech potencjałów, ale stany wywołujące artefakty miały różne skutki.

Wnioski: Nie wszystkie artefakty miały jednakowy wpływ na słuchowe potencjały wywołane. Aby uzyskać dobre sygnały słuchowych potencjałów wywołanych niezbędne jest dokładne zrozumienie różnych potencjałów mięśniowych i ich odpowiednich wpływów na każdy potencjał AEP.

Słowa kluczowe: artefakty • słuchowe potencjały wywołane • stosunek sygnału do szumu

\section{Background}

Auditory evoked potentials (AEPs) are indispensable components of the audiological test battery. In the clinic they provide reliable estimates of hearing thresholds [1-10] and help to detect space-occupying or diffuse lesions in the auditory pathway [11-17]. In the laboratory they are also used to understand the neural mechanisms of peripheral and central auditory processing under various listening conditions [2,18-26].

Far-field recording of AEPs is always a challenge due to their low amplitude. In addition, AEPs are always recorded in the presence of background electroencephalographic (EEG) activity (in other words, artifacts), so the aim in recording AEPs is to reduce background noise and enhance the signal-to-noise ratio. This task requires use of several signal enhancement strategies such as differential amplification, filtering, averaging, and artifact rejection [27-30].

The most common source of noise which can have deleterious effects on AEP recordings are muscle potentials $[29,31,32]$. If muscle activity generates potentials that have the same frequency as that of the target AEP (either auditory brainstem response, $\mathrm{ABR}$; middle latency response, MLR; or late latency response, LLR), it is likely to be picked up, amplified, and averaged, thereby negatively affecting the signal-to-noise ratio. These potentials are relatively large in amplitude [33] and can either be from single or multiple muscle sites in the body. Some muscle activities that are known to affect AEP recordings include eye blinks, teeth clenching, neck stiffening, limb movement, swallowing, and the like $[27,29,34]$.

All agree that muscle artifacts have a negative effect on AEPs. It has therefore become common practice to instruct the patient to relax, sit in a comfortable position, not move, minimize blinking, not speak, and keep the head still. This instruction remains the same irrespective of the auditory potential being recorded (ABR, MLR, or LLR).

To remove muscle artifacts during AEP recording, an appropriate artifact rejection threshold must be set. The threshold is based on the assumption that muscle artifacts are of high amplitude. Any recording sweep with significant muscle artifacts will have an amplitude higher than the artifact rejection window and is therefore likely to be rejected and not considered for averaging, thereby ensuring good signal-to-noise ratio. The artifact rejection window is generally varied depending on the AEP being recorded. It is conventional to set the artifact rejection window at around $\pm 25 \mu \mathrm{V}$ for ABR, $\pm 50 \mu \mathrm{V}$ for MLR, and $\pm 100 \mu \mathrm{V}$ for LLR $[27,35]$, but a review of literature suggests this recommendation is not evidence-based. In addition, when recording AEPs most audiologists have a tendency to increase the artifact rejection threshold beyond the recommended limits, for example when an EEG has poor SNR.

Artifact rejection affects test efficiency, and the optimum level depends on the prevailing test conditions, which can change during the recording. It is important that audiologists are aware of this and develop evidence-based skills to optimize test quality, particularly under challenging test conditions [36]. Although it is well known that muscle artifacts impair AEP recordings, the precise relation between a set of muscles and a specific AEP is not clear. Most audiologists believe that increases in the tension of any muscle affects all AEPs to the same extent, while others believe that only the head and neck muscles are important. Logically, this relation will depend on the frequency characteristics of the muscle artifact.

The particular artifact rejection level chosen for an AEP recording is crucial in obtaining waveforms with good signal-to-noise ratio, but its importance is underestimated by most testers [36]. The tendency of most audiologists to increase the artifact rejection level and set a higher number of sweeps for averaging will result in waveforms with poor morphology and lead to false negatives in AEP detection. According to Hall [27], for effective artifact rejection one needs to have a clear understanding of artifact amplitudes. However, to the best of our knowledge, there is no scientific documentation of the amplitude of artifacts and the extent of interference created by various muscle artifacts on ABR, MLR, and LLR. Hence, the present study.

We wanted to answer the following questions. Are all muscle responses deleterious for all AEPs? Which muscle responses need to be controlled for which AEP? What is the ideal artifact rejection threshold for ABR, MLR, and LLR under various artifact-inducing conditions? 
Table 1. Stimulus and acquisition parameters used to record $A B R, M L R$, and LLR

\begin{tabular}{|c|c|c|c|}
\hline \multirow{2}{*}{ Parameter name } & \multicolumn{3}{|c|}{ Stimulus parameters } \\
\hline & ABR & MLR & LLR \\
\hline Transducer & ER3A insert ear phone & ER3A insert ear phone & ER3A insert ear phone \\
\hline Stimulus & Click (100 ㅆs) & 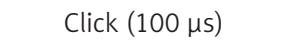 & Click $(100 \mu s)$ \\
\hline Stimulus repetition rate & 30.1 per second & 7.1 per second & 1.1 per second \\
\hline Polarity & Rarefaction & Rarefaction & Rarefaction \\
\hline Stimuli number & 1000 & 1000 & 250 \\
\hline Ear stimulated & Right & Right & Right \\
\hline \multirow[t]{2}{*}{ Intensity level } & $70 \mathrm{dBnHL}$ & $70 \mathrm{dBnHL}$ & $70 \mathrm{dBnHL}$ \\
\hline & \multicolumn{3}{|c|}{ Acquisition parameters } \\
\hline Gain & $100000 x$ & $50000 x$ & $25000 x$ \\
\hline Filter & $30-3000 \mathrm{~Hz}$ & $10-1500 \mathrm{~Hz}$ & $1-30 \mathrm{~Hz}$ \\
\hline Electrode montage & $\begin{array}{c}\text { Non-inverting }-\mathrm{Fz} \\
\text { Inverting - M1 } \\
\text { Ground - M2 }\end{array}$ & $\begin{array}{c}\text { Non-inverting }-\mathrm{Fz} \\
\text { Inverting - M1 } \\
\text { Ground - M2 }\end{array}$ & $\begin{array}{c}\text { Non-inverting }-\mathrm{Fz} \\
\text { Inverting - M1 } \\
\text { Ground - M2 }\end{array}$ \\
\hline
\end{tabular}

\section{Material and methods}

The study aimed to test the null hypothesis that there is no relationship between the type of artifact and the type of AEP. A factorial design was adopted to verify this hypothesis. The methods employed in collection of data, data analysis, and data reporting conformed to accepted standards $[37,38]$ for event related potentials. Additionally the protocols used in the study conformed to the ethical guidelines for bio-behavioural research involving human subjects set by the All India Institute of Speech and Hearing [39], and also the declaration of Helsinki [40].

\section{Participants}

Forty healthy individuals (20 males and 20 females) of age 17 to 24 years participated in the study. All were graduate or post-graduate students of speech and hearing, and had normal hearing sensitivity. Normal hearing was gauged by pure tone audiometry in which pure tone thresholds of each ear were less than $15 \mathrm{dBHL}$ at octave frequencies between 250 and $8000 \mathrm{~Hz}$. A calibrated Orbiter 922 with standard accessories was used for this purpose. The participants also had type-A tympanograms and acoustic reflexes present bilaterally which indicated normal middle ear functioning [41]. Immittance evaluation was carried out using a calibrated GSI-Tympstar with standard accessories. Written prior consent was obtained from all participants.

\section{Recording of AEPs}

AEPs were recorded in the electrophysiology laboratory of the Department of Audiology of the All India Institute of Speech and Hearing, Mysore. The recording room was electrically shielded with ambient noise levels less than 36
dBSPL. After explaining the purpose and protocol of the study, a participant was comfortably seated in a reclining chair. Intelligent Hearing Systems equipment with SmartEP (version 3.95) was used for recording AEPs. Three electrode sites $(\mathrm{FPz}, \mathrm{M} 1$, and $\mathrm{M} 2$ according to the international 10-20 system) were cleaned and silver chloride electrodes were placed using conducting gel and tape. After ensuring inter-electrode impedance of $<2 \mathrm{k} \Omega$ and absolute electrode impedance of $<5 \mathrm{k} \Omega$, responses were recorded from these electrodes in vertical montage, with $\mathrm{FPz}$ being noninverting, M2 inverting, and M1 ground.

Click stimuli were presented monoaurally to the right ear at $70 \mathrm{dBnHL}$ through ER-3A insert earphones. ABRs, MLRs, and LLRs were recorded from each participant using the respective protocols as advised by Hall [27]. The analysis window, filter setting, and repetition rate of the stimuli, number of sweeps, and gain depended on the potential being recorded. The stimulus and acquisition parameters are given in Table 1.

In each recording, the online EEG was monitored to set the minimum artifact rejection window (in microvolts) such that an average response of 1000 sweeps (250 sweeps in the case of LLR) could be recorded with less than $10 \%$ sweep rejections. This level was operationally termed the 'Minimum Artifact Rejection Threshold' (MART). The MART served as an estimate of the amplitude of the muscle artifact. The artifact rejection threshold was varied in steps of $5 \mu \mathrm{V}$ and this task was done under six conditions for which the tone of different sets of muscles was actively varied. The MART has been illustrated in Figure 1.

Initially, the recording was done in the rest condition, where participants were seated in a reclining chair and 
A
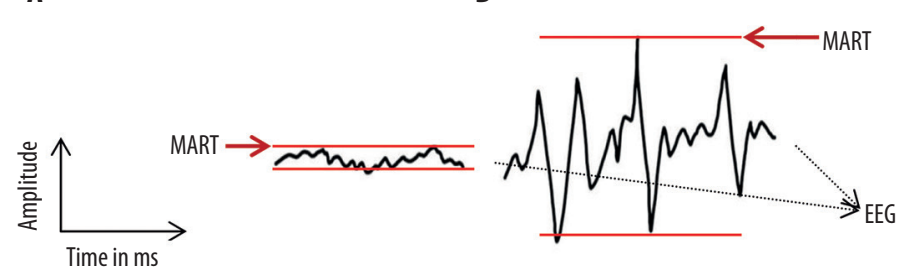

Figure 1. Illustration of the minimum artifact rejection thresholds (MARTs) for a low amplitude artifact (A) and a high amplitude artifact (B). In both cases the red lines show a MART at which $10 \%$ of the sweeps are rejected

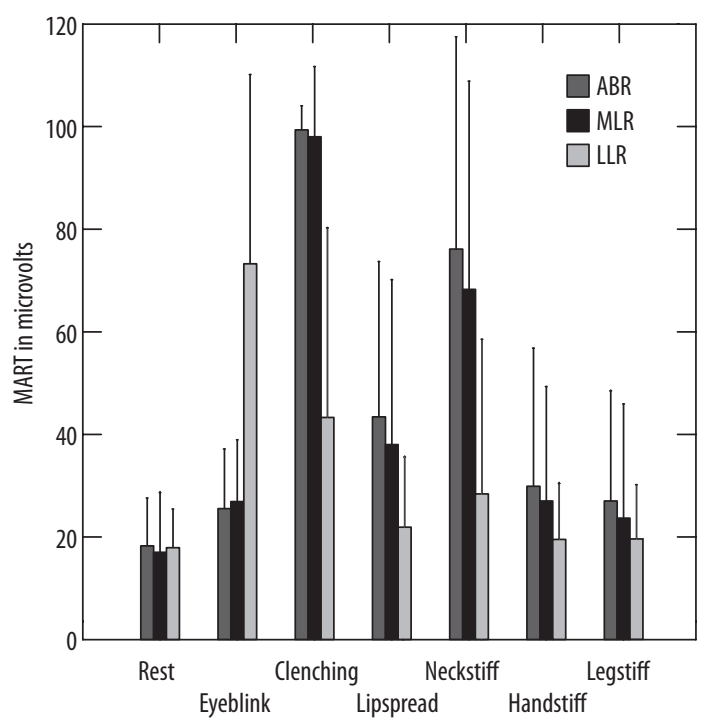

Figure 2. MART levels $(\mu \mathrm{V})$ under different muscle conditions for which 1000 sweeps (250 sweeps in the case of LLR) could be recorded with less than $10 \%$ rejections. Coloured bars are for ABR, MLR, and LLR recording protocols. Error bars indicate standard deviation

asked to close their eyes and maintain a relaxed position. Following this, the participants were asked to carry out each of the following tasks: blink the eyes continuously (eyeblink), clench the teeth (clenching), spread the lips by pulling the corner of lips backwards as in a forced smile (lipspread), stiffen the neck (neckstiff), stiffen the hand (handstiff), and stiffen the leg (legstiff) muscles maximally. While tensing each of these sets of muscles, the MART was noted. These six conditions were set based on the clinical experience of recording AEPs.

\section{Statistical analysis}

The individual data was tabulated and group data analysed using Repeated Measures Analysis of Variance (RMANOVA) to verify the significant main effect of artifacts on AEPs. The main effect of gender was also analysed. Pairwise comparisons were performed using Bonferroni's test wherever there was a significant main effect.

\section{Results}

The mean and standard deviation of MART in the seven conditions ( 1 rest and 6 artifact conditions) across the three AEPs (ABR, MLR, and LLR) are shown in Figure 2. It can be seen that the mean MART varies with the type of muscle artifact and the type of AEP recorded. Figure 2 shows that for ABR and MLR the largest MART level occurred during teeth clenching, while for LLR it occurred during eyeblinks. In all cases, the smallest MART levels were seen in the rest condition. Stiffening of the hand or leg muscles did not seem to have elevated the mean MART level beyond that in rest for all the three AEPs. It can also be seen that the mean MART levels in ABR and MLR seem to match across artifact conditions, whereas for LLR the MART levels differed. Results and the outcome of statistical treatment are discussed in detail in subsequent sections.

\section{Results of MARTs at rest}

The mean MART level was less than $20 \mu \mathrm{V}$ for all three AEPs at rest. The standard deviations were similar across the three AEPs. Repeated measures ANOVA (RMANOVA) confirmed that there was no statistically significant difference in MART across the three AEPs $[F(2,76)=1.494, p>0.05]$ at rest. The results were true for both males and females.

\section{Results of MARTs under artifact-inducing conditions}

Unlike the rest condition, the different artifact-inducing conditions showed differential effects across the three AEPs. There was a significant main effect of AEP protocol on the MART during continuous eyeblinks $[F(2,76)=434.05, p<0.001]$, teeth clenching $[F(2,76)=363.421, p<0.001]$, lip spreading $[F(2,76)=58.544$, $p<0.001]$, neck stiffening $[F(2,76)=162.512, p<0.001]$, hand stiffening $[F(2,76)=24.235, p<0.001]$, and leg stiffening $[F(2,76)=18.003, p<0.001]$.

Additionally, there was a significant gender $\times$ condition interaction for eyeblinks $[F(2,76)=1320.625, p<0.001]$, hand stiffening $[F(2,76)=227.708, p<0.05]$, and leg stiffening $[F(2,76)=277.708, p<0.001]$. The same however was not found for teeth clenching $[\mathrm{F}(2,76)=41.875, p>0.05]$, lip spreading $[F(2,76)=25.208, p>0.05]$, and neck stiffening $[F(2,76)=31.458, p>0.05]$. Females showed significantly higher MART levels than males during eye blinking, neck stiffening, hand stiffening, and leg stiffening. Since there was a significant gender $\times$ condition interaction, separate RMANOVA with Bonferroni's pairwise comparisons were carried out for data of males and females. The means and standard deviations of the MART levels across the artifact-inducing conditions for the male and female participants are shown in Figure 3.

\section{Results in males}

RMANOVA showed a significant main effect of condition on $\operatorname{ABR}[F(6,114)=183.43, p<0.001]$, MLR 
A

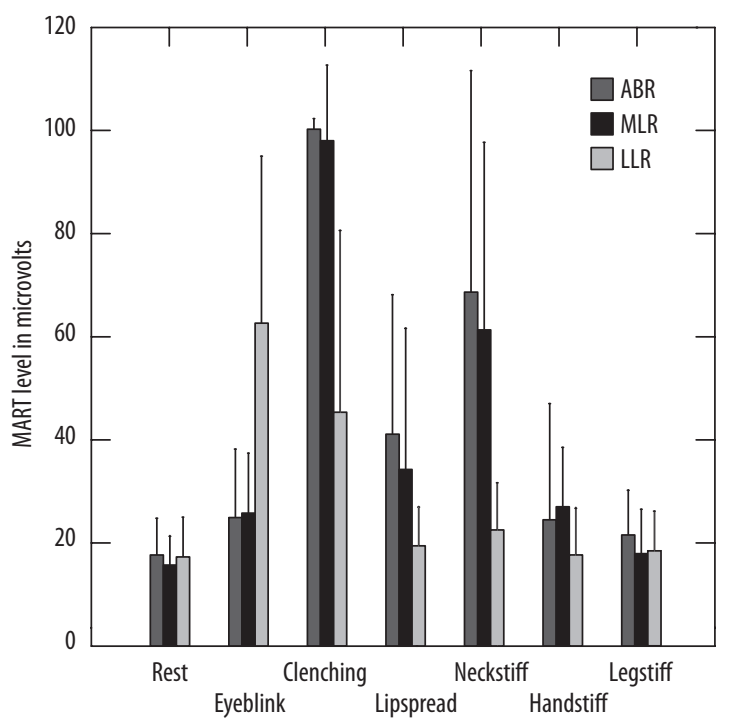

Figure 3. MART levels in males (A) and females (B)

$[F(6,114)=213.365, p<0.001]$, and $\operatorname{LLR}[F(6,114)=75.707$, $p<0.001]$. The data was further subjected to Bonferroni's pairwise comparison to determine the artifact-inducing conditions under which the MART levels differed/did not differ significantly.

In the ABR and MLR protocol the MART levels were the highest during teeth clenching followed by neck stiffening and lip spreading. The remainder of the artifact-inducing conditions had significantly lower and similar MART levels (with the exception of eye blinking which had slightly higher statistically significant MART levels) compared to rest.

In the LLR protocol, MART levels were highest during eye blinking followed by teeth clenching, while the other artifact-inducing conditions had lower and similar MART levels as in the rest condition. The only exception was neck stiffening, which had slightly but statistically higher MART levels than the rest condition.

\section{Results in females}

In the ABR and MLR protocols, MART levels were highest during teeth clenching followed by neck stiffening and lip spreading. The remainder of the artifact-inducing conditions had significantly lower and similar MART levels. All the artifact-inducing conditions showed significantly higher MART levels than that during rest. This was in contrast to the findings in males where the MART levels during hand and leg stiffening were similar to those seen in rest.

In the LLR protocol, MART levels were highest during eye blinks, followed by teeth clenching. MART levels during teeth clenching were similar to those during neck stiffening and significantly higher than the rest of the artifactinducing conditions except eye blinking. Neck stiffening led to significantly higher MART levels than the other artifact-inducing conditions except for eye blinking and teeth clenching. This was in contrast to the findings in males.
B

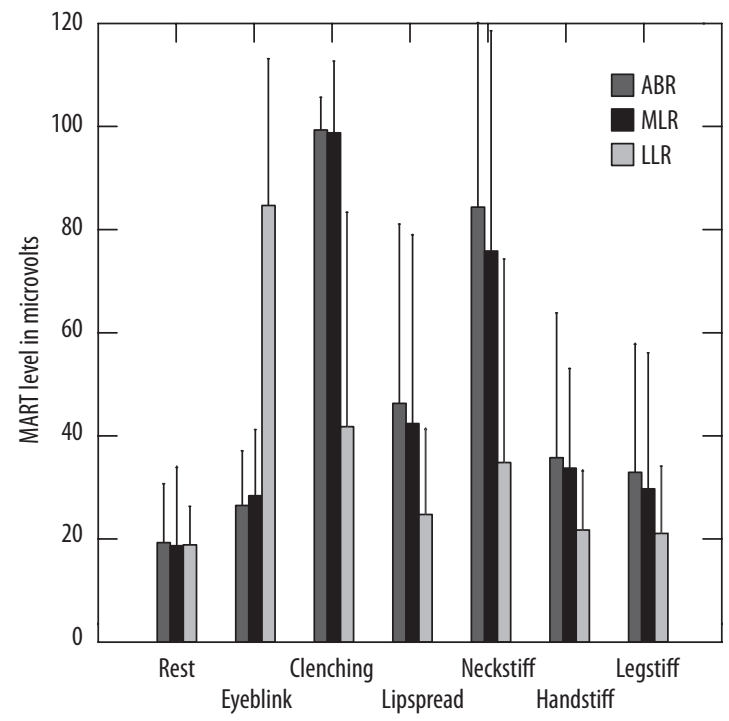

MART levels during hand and leg stiffening were similar to those in rest.

\section{Discussion}

The present study tested the null hypothesis that there was no significant relation between type of artifact and type of AEP. However, findings do not support the null hypothesis as there were different effects from various muscle artifacts across the three AEPs chosen. We now address each of the research questions.

What is the ideal artifact rejection window for ABR, MLR, and LLR?

Muscle potential artifacts are frequently encountered during AEP recordings [29]. To minimise artifacts, the person being tested is always instructed to relax, sit in a comfortable position, and not move. Supporting the validity of this instruction, in the present study the least MART was noted in the rest condition. In this condition, MART levels did not vary significantly across the three AEPs. It can therefore be inferred that the artifact rejection window set for ABR, MLR, and LLR can remain the same, unlike the traditional approach of using higher artifact rejection windows for higher potentials. Based on the data of the present study, it is advised to keep the rejection window to less than $\pm 20 \mu \mathrm{V}$ for EEGs with good SNR to produce a reliable AEP.

Historically, the artifact rejection window is varied depending on the AEP being recorded. It is usual to set the artifact rejection window at around $\pm 25 \mu \mathrm{V}$ for $\mathrm{ABR}$, $\pm 40 \mu \mathrm{V}$ for MLR, and $\pm 50 \mu \mathrm{V}$ for LLR, but a review of the literature indicates these values seem to be convention only and not based on evidence. The present finding that there is no significant difference in the mean MART across the three AEPs does not support the conventional approach. It suggests, somewhat surprisingly, that the 


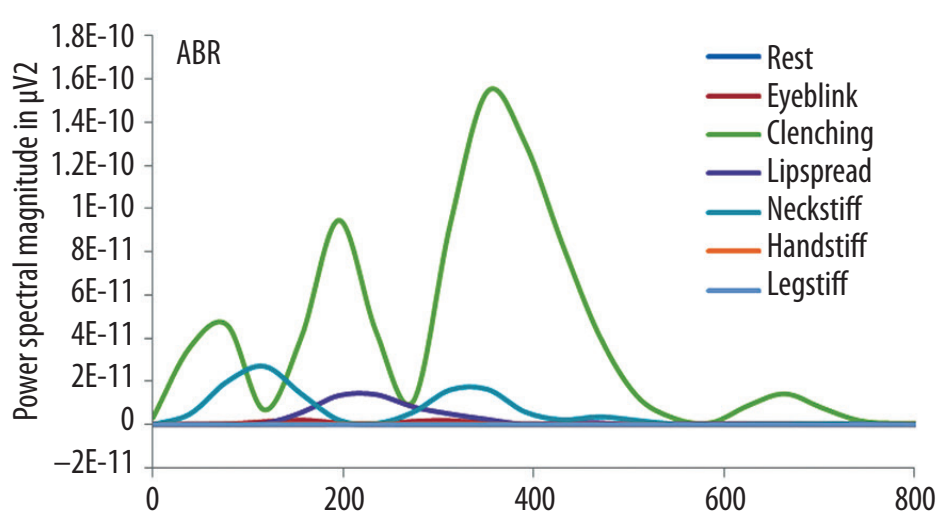

Figure 4. Power spectra of single trial EEGs under various artifact-inducing conditions for $A B R, M L R$, and LLR protocols
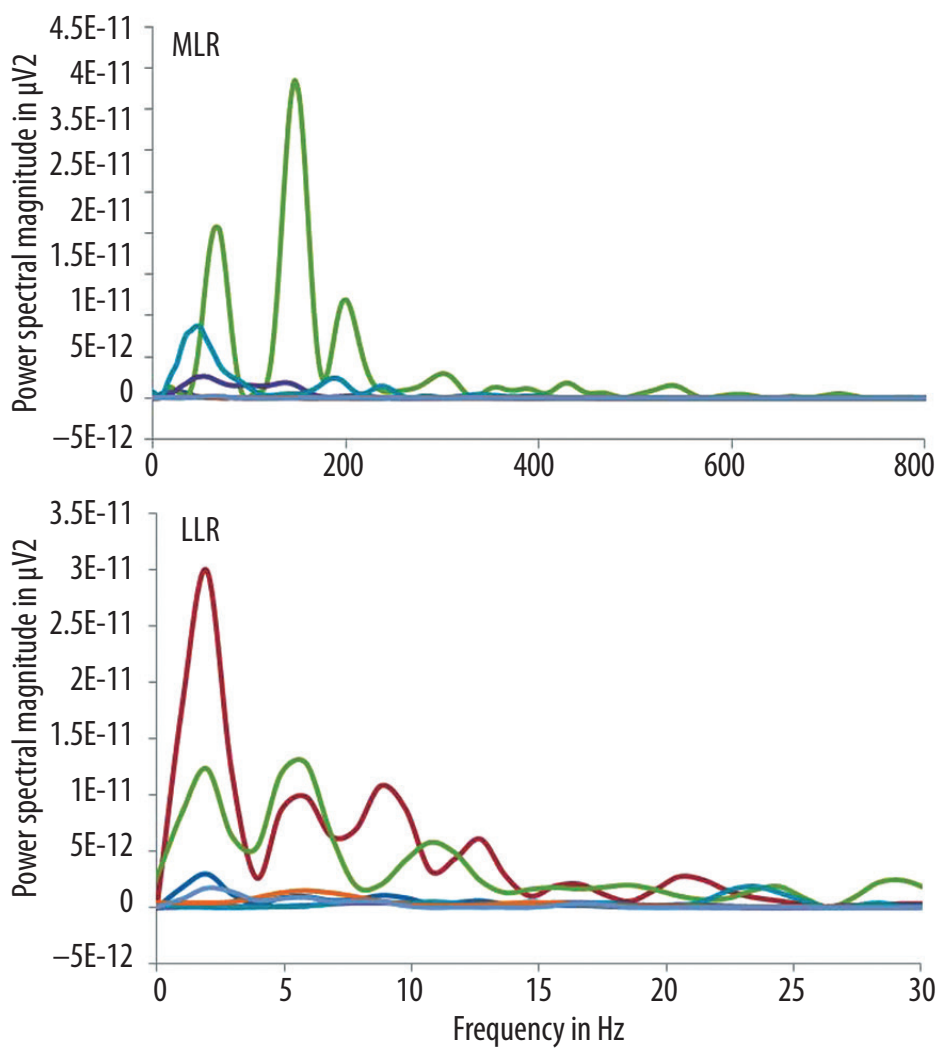

rejection window should be constant irrespective of the AEP being recorded.

A further practical consideration is that many audiologists, when recording AEPs from EEGs with poor SNR, tend to increase the artifact rejection threshold beyond recommended limits. This is not advised as it will still include artifacts in the averaging, leading to waveforms with poorer SNRs. In instances of poor EEGs, one should identify the specific muscle artifact that is causing the interference and try to remove it by encouraging relaxation. It is not correct to increase the rejection window.

\section{Do all muscle responses impair all AEPs?}

Results of the present study show that each of the artifact-inducing conditions affected the three target AEPs differently and every muscle artifact was not deleterious to all AEPs.

For ABRs and MLRs, the pattern of muscle interference was the same. Both these potentials received interference largely from head and neck muscles. Hand and leg stiffening did not have much of an effect on them. The strongest interference came from jaw muscles (teeth clenching), followed by neck muscles, lip and cheek muscles, and eye blinks. Although eye blink interference was the smallest, it was still significantly above the resting state. Thus, when recording ABRs or MLRs, the major concern is the head and neck muscles.

The mean level of interference obtained from different artifact-inducing actions provides some valuable clinical hints. In particular, if one finds a large level of interference 

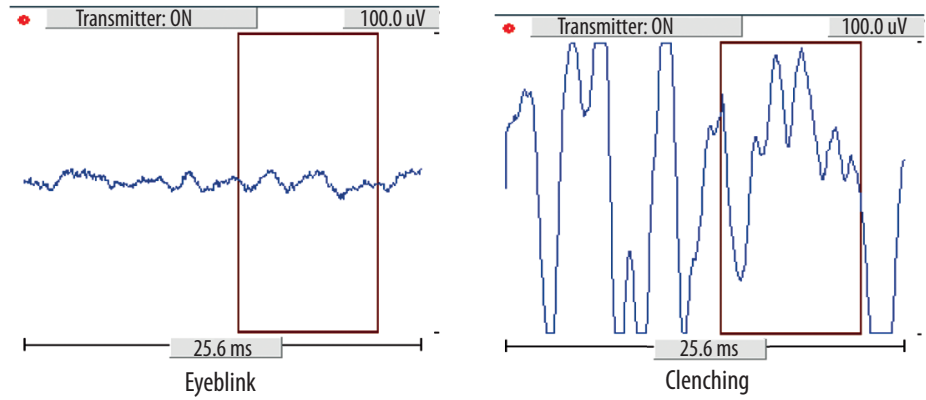

Figure 5. EEG windows in a representative subject showing artifacts in the time domain during artifact-eliciting tasks in the ABR protocol
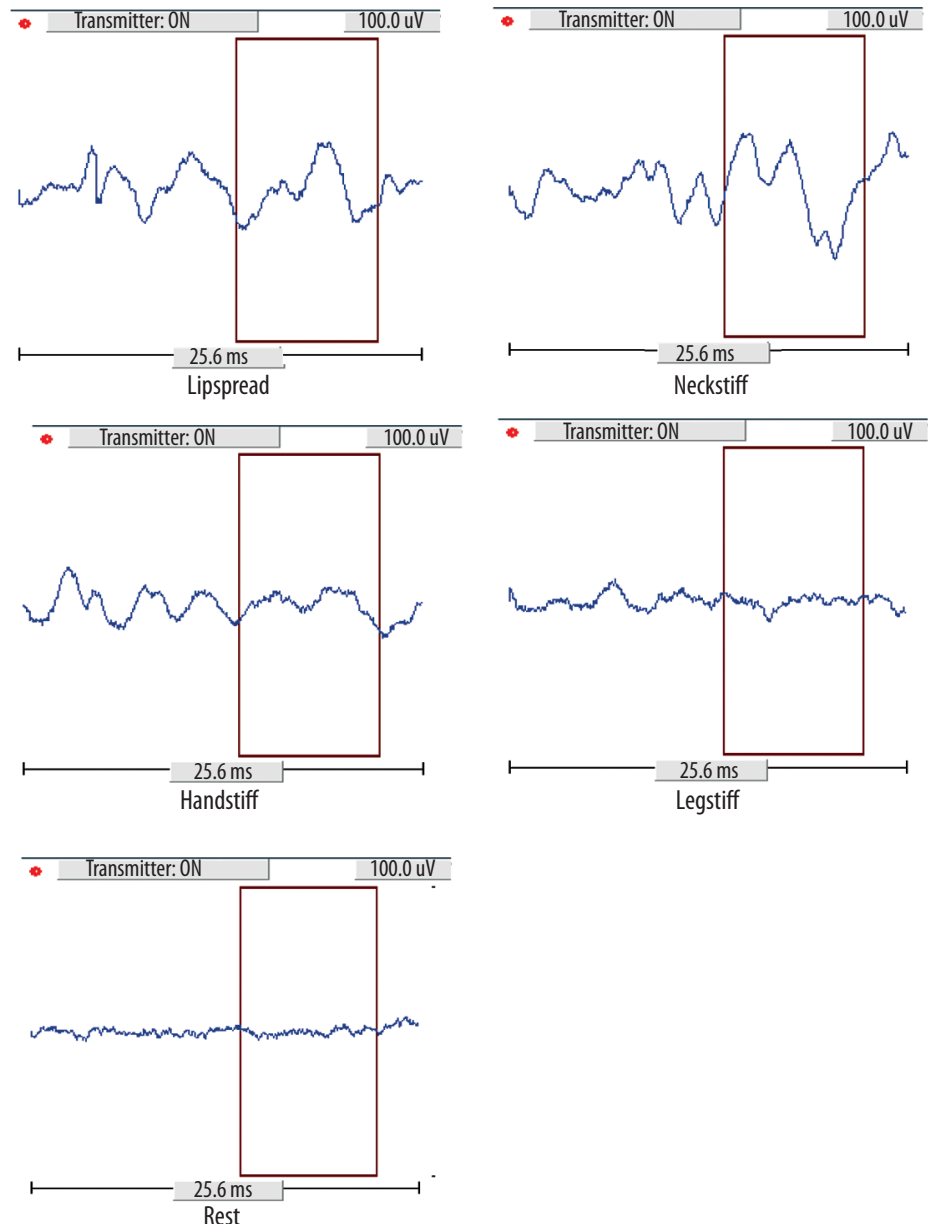

during ABR and MLR recordings, it is likely to come from either teeth clenching, neck stiffening, or lip spreading. On the other hand if the interference is smaller, it is likely to come from eye blinks. Based on the present findings, the instruction to the patient before recording an $\mathrm{ABR}$ or MLR should be to relax the jaw, cheek, and neck muscles and minimize eye blinks. The patient does not need to close their eyes.

During LLR recordings, the maximum interference came from eye blinks, followed by teeth clenching and neck stiffening. Therefore, the biggest problem is eyeblinks, even though they appear to be rather a subtle activity. Interference from eye blinks can be of large amplitude and impair
LLR recordings. Blinking can be minimized by instructing the patient accordingly, but the ideal method is to remove them from averaging by having a dedicated channel to record eye blinks.

The finding that different sets of muscles are responsible for interfering with ABR, MLR, and LLR can be attributed to the particular frequency characteristics of the muscle potentials and their strength (Figure 4). Teeth clenching and neck stiffening affect all three potentials because they seem to have a broad frequency range. However, eye blinks affect only LLR because they display low frequency electrical activity. If an artifact-inducing activity does not affect a particular AEP, it means the muscle potential 

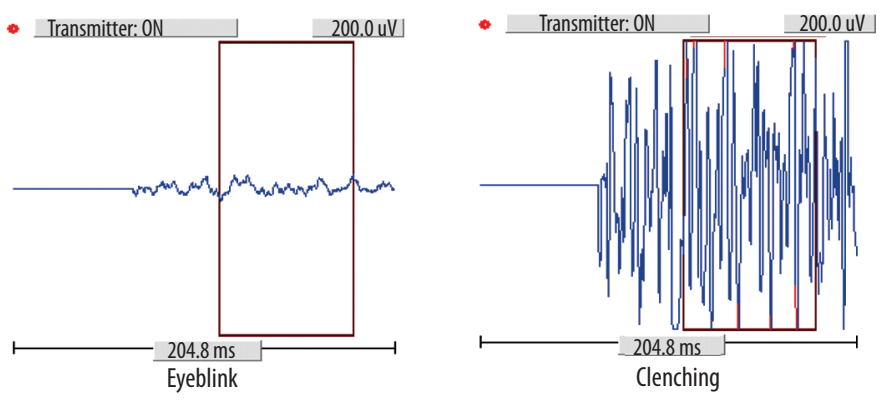

Figure 6. EEG windows in a representative subject showing artifacts in the time domain during artifact-eliciting tasks in the MLR protocol
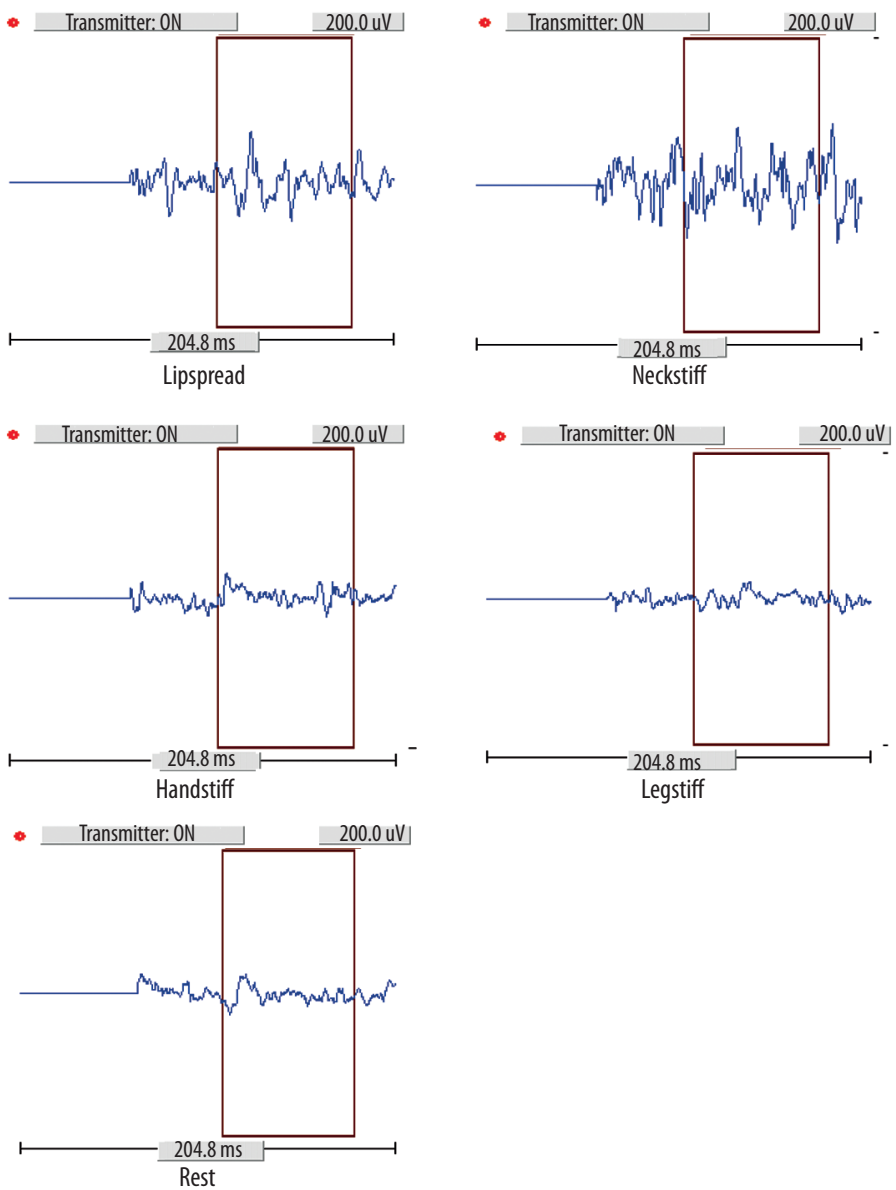

egstiff

generated does not fall within the passband of the filter or its strength at the target electrode is not sufficient to cause interference. Figures 5-7 show time domain representations of each of the artifacts displayed in the online EEG window.

\section{Effect of gender on MART}

The present study also showed gender differences in the MART, suggesting that interference is more likely to occur in females than in males. Although the reason is not clear, one can speculate that it is either because net muscle tone built up is relatively higher in females or that they conduct muscle potentials better.
Overall, the findings suggest that before thinking about any strategy to reduce artifacts one should identify which muscles are tense and which AEP is being recorded. For example, if the subject has continuous eye blinks during ABR recording, it should be less troublesome than other artifacts. Similarly, if the body muscles of the subject are stiff during LLR recording but they have negligible eye blinks, one can still continue with the recording, albeit with caution. The relation between muscle artifacts and AEPs depends on overlapping frequency responses.

For clinical utility, an attempt was made in the present study to derive an advisable range of artifact rejection windows for ABR, MLR, and LLR. This was done by deriving 

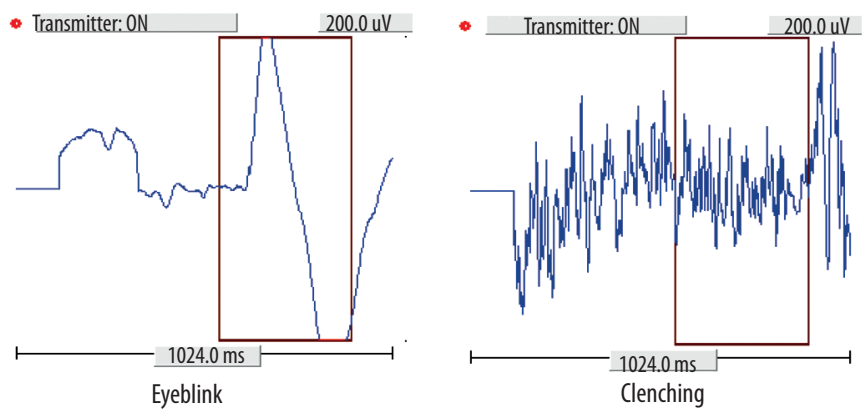

Figure 7. EEG windows in a representative subject showing artifacts in the time domain during artifact-eliciting tasks in the LLR protocol
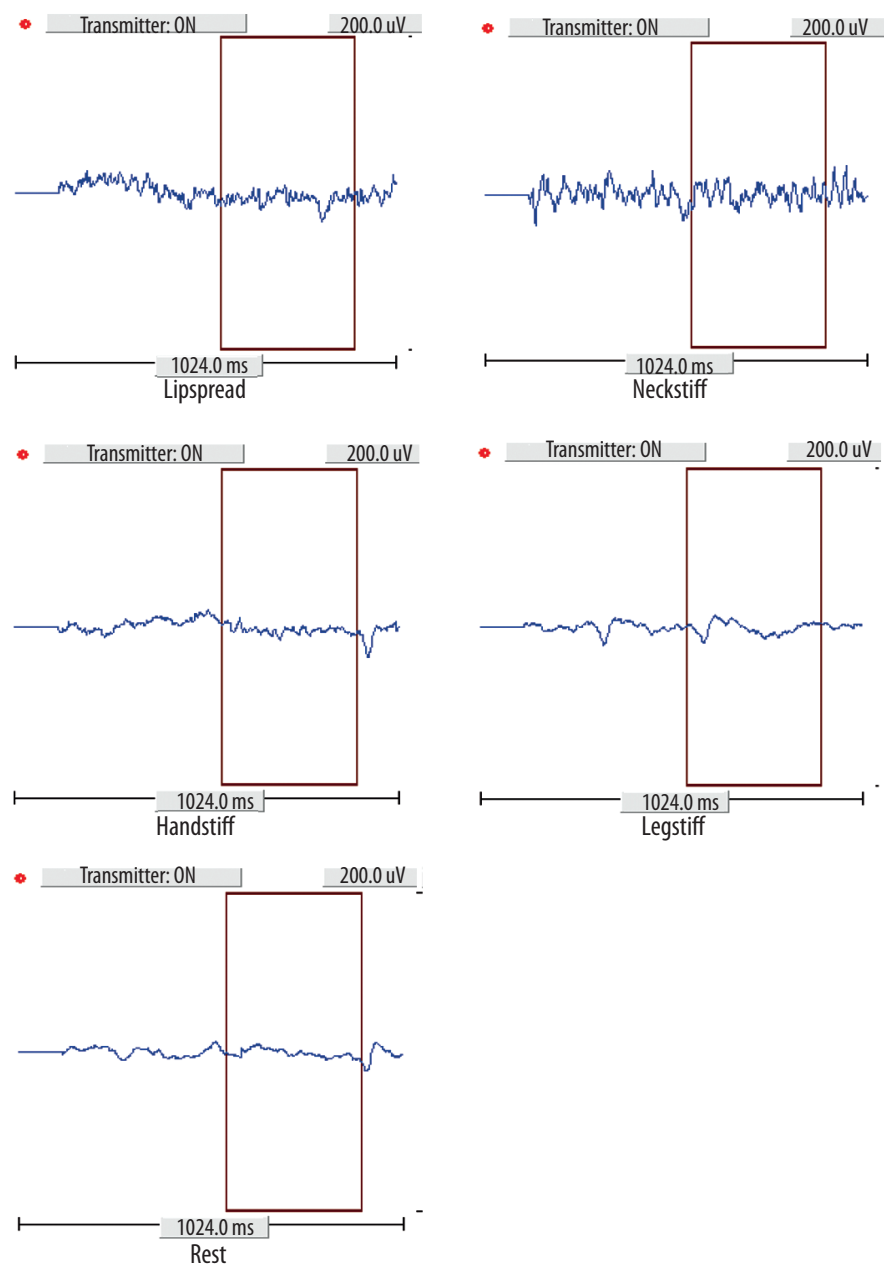

Table 2. Minimum, maximum, and confidence limits of artifact window derived from the present data

\begin{tabular}{cccc}
\hline & \multicolumn{3}{c}{ Advisory artifact rejection window } \\
\cline { 2 - 4 } AEP & Minimum $(\mu \mathrm{V})$ & Maximum $(\boldsymbol{\mu V})$ & $\begin{array}{c}\text { Confidence interval }(\boldsymbol{\mu V}) \\
\mathbf{( 5 - 9 5 \% )}\end{array}$ \\
\hline ABR & 10 & 35 & $16.8-19.7$ \\
\hline MLR & 10 & 45 & $15.2-18.2$ \\
\hline LLR & 10 & 25 & $16.7-19.1$ \\
\hline
\end{tabular}


the confidence intervals and extremes of MARTs in the rest condition. The data are shown in Table 2.

\section{Conclusions}

From the findings of the present study, it can be concluded that not all artifacts affect every AEP equally. Instead, one needs to have a clear understanding of various muscle potentials and the specific potentials that affect AEPs. It does not follow an 'all or none' principle.

\section{Acknowledgements}

We acknowledge the Director, All India Institute of Speech and Hearing, for providing necessary infrastructure. We extend our sincere thanks to the HOD, Audiology, and all participants. We are grateful to two anonymous reviewers for useful comments on an earlier version of this manuscript.

\section{References:}

1. Joint Committee on Infant Hearing. Year 2007 Position Statement: Principles and Guidelines for Early Hearing Detection and Intervention Programs. Pediatrics, 2007; 120: 898-921.

2. Kouni SN, Giannopoulos S, Ziavra N, Koutsojannis C. Brainstem auditory evoked potentials with the use of acoustic clicks and complex verbal sounds in young adults with learning disabilities. Am J Otolaryngol, 2013; 34: 646-51.

3. Sohmer H, Kinarti R. Survey of attempts to use auditory evoked potentials to obtain an audiogram. Br J Audiol, 1984; 18: 237-44.

4. Vander Werff KR, Brown CJ. Effect of audiometric configuration on threshold and suprathreshold auditory steady-state responses. Ear Hear, 2005; 26: 310-26.

5. Lightfoot G, Kennedy V. Cortical electric response audiometry hearing threshold estimation: accuracy, speed, and the effects of stimulus presentation features. Ear Hear, 2006; 27: 443-56.

6. Stapells DR. Threshold estimation by the tone evoked auditory brainstem response: a literature meta-analysis. J Speech Lang Pathol Audiol, 2000; 24: 74-83.

7. Werner LA, Folsom RC, Mancl LR. The relationship between auditory brainstem response and behavioral thresholds in normal hearing infants and adults. Hear Res, 1993; 68: 131-41.

8. Lightfoot G, Stevens J. Effects of artefact rejection and Bayesian weighted averaging on the efficiency of recording the newborn ABR. Ear Hear, 2014; 35: 213-20.

9. Trzaskowski B, Jedrzejczak WW, Pilka E, Kochanek K, Skarzynski $\mathrm{H}$. Automatic removal of sonomotor waves from auditory brainstem responses. Comput Biol Med, 2013; 43: 524-32.

10. Sanchez JT, Gans D. Effects of artifact rejection and bayesian weighting on the auditory brainstem response during quiet and active behavioral conditions. Am J Audiol, 2006; 15: 154-63.

11. Chandrasekhar SS, Brackmann DE, Devgan KK. Utility of auditory brainstem response audiometry in diagnosis of acoustic neuromas. Am J Otol, 1995; 16: 63-7.

12. Don M, Masuda A, Nelson R, Brackmann D. Successful detection of small acoustic tumors using the stacked derived-band auditory brain stem response amplitude. Am J Otol, 1997; 18: 608-21; discussion 682-5.

13. Paludetti G, Ottaviani F, Gallai V, Tassoni A, Maurizi M. Auditory brainstem responses (ABR) in multiple sclerosis. Scand Audiol, 1985; 14: 27-34.

14. Bozorg Grayeli A, Refass A, Smail M, Elgarem H, Kalamarides M, Bouccara D et al. Diagnostic value of auditory brainstem responses in cerebellopontine angle tumours. Acta Otolaryngol (Stockh), 2008; 128: 1096-100.

15. Cashman MZ, Rossman RN. Diagnostic features of the auditory brainstem response in identifying cerebellopontine angle tumours. Scand Audiol, 1983; 12: 35-41.
16. Paludetti G, Ottaviani F, Gallai V, Tassoni A, Maurizi M. Auditory brainstem responses (ABR) in multiple sclerosis. Scand Audiol, 1985; 14: 27-34.

17. Saberi A, Hatamian HR, Nemati S, Banan R. Hearing statement in multiple sclerosis: a case control study using auditory brainstem responses and otoacoustic emissions. Acta Med Iran, 2012; 50: 679-83.

18. Anderson S, Skoe E, Chandrasekaran B, Kraus N. Neural timing is linked to speech perception in noise. J Neurosci, 2010; 30: 4922-6.

19. Galbraith GC1, Threadgill MR, Hemsley J, Salour K, Songdej N, Ton J et al. Putative measure of peripheral and brainstem frequency-following in humans. Neurosci Lett, 2000; 292: 123-7.

20. Maruthy S, Mannarukrishnaiah J. Effect of early onset otitis media on brainstem and cortical auditory processing. Behav Brain Funct, 2008; 4: 17.

21. Kraus N, Anderson S. The effects of aging on auditory processing. Hear J, 2013; 66: 36.

22. Anderson S, Parbery-Clark A, Yi H-G, Kraus N. A neural basis of speech-in-noise perception in older adults. Ear Hear, 2011; 32: 750-7.

23. Krishnan A, Gandour JT, Bidelman GM. Experience-dependent plasticity in pitch encoding: from brainstem to auditory cortex. NeuroReport. 2012;23: 498-502.

24. Ganapathy MK, Narne VK, Kalaiah MK, Manjula P. Effect of pre-transition stimulus duration on acoustic change complex. Int J Audiol, 2013; 52: 350-9.

25. Billings CJ, Tremblay KL, Miller CW. Aided cortical auditory evoked potentials in response to changes in hearing aid gain. Int J Audiol, 2011; 50: 459-67.

26. Souza PE, Boike KT, Witherell K, Tremblay K. Prediction of speech recognition from audibility in older listeners with hearing loss: effects of age, amplification, and background noise. J Am Acad Audiol, 2007; 18: 54-65.

27. Hall JW. New Handbook of Auditory Evoked Responses. Pearson; 2007.

28. Hood LJ. Clinical Applications of the Auditory Brainstem Response. 1st ed. San Diego: Singular Publishing; 1998.

29. Jacobson JT. Principles and Applications in Auditory Evoked Potentials. Allyn and Bacon; 1994.

30. Moore EJ. Bases of Auditory Brain-stem Evoked Responses. Grune \& Stratton; 1983.

31. Guerreiro CA, Ehrenberg BL. Brainstem auditory evoked response. Available from $h t t p: / / w w w . s c i e l o . b r / p d f / a n p / v 40 n 1 / 03$. $p d f$, viewed 2015 Oct 12

32. Picton TW, Woods DL, Baribeau-Braun J, Healey TM. Evoked potential audiometry. J Otolaryngol, 1976; 6: 90-119. 
33. Sokolov Y, Kurtz I, Steinman A, Long G, Sokolova O. Integrity technology: enabling practical ABR Available from: $h t t p: / /$ www.vivosonic.com/en/support/files/Integrity-Technology-2005. pdf, viewed 2014 Nov 24.

34. Croft RJ, Barry RJ. Removal of ocular artifact from the EEG: a review. Neurophysiol Clin, 2000; 30: 5-19.

35. Hall JW. Handbook of Auditory Evoked Responses. Allyn and Bacon; 1992.

36. Ferm I, Lightfoot G, Stevens J. Comparison of ABR response amplitude, test time, and estimation of hearing threshold using frequency specific chirp and tone pip stimuli in newborns. Int J Audiol, 2013; 52: 419-23.

37. Duncan CC, Barry RJ, Connolly JF, Fischer C, Michie PT, Näätänen R et al. Event-related potentials in clinical research: guidelines for eliciting, recording, and quantifying mismatch negativity, P300, and N400. Clin Neurophysiol, 2009; 120: 1883-908.
38. Picton TW, Bentin S, Berg P, Donchin E, Hillyard SA, Johnson R Jr et al. Guidelines for using human event-related potentials to study cognition: recording standards and publication criteria. Psychophysiology, 2000; 37: 127-52.

39. Venkatesan S. Ethical guidelines for bio-behavioral research involving human subjects. All India Institute of Speech and Hearing, Manasagangothri, Mysore; 2009. Available from: $h t t p: / /$ www.aiishmysore.in/en/pdf/ethical_guidelines.pdf, viewed 2015 Oct 13.

40. WMA Declaration of Helsinki - Ethical Principles for Medical Research Involving Human Subjects 2013. Available from: http://www.wma.net/en/30publications/10policies/b3/, viewed 2015 Oct 13.

41. Jerger J. Clinical experience with impedance audiometry. Arch Otolaryngol, 1970; 92: 311-24. 